
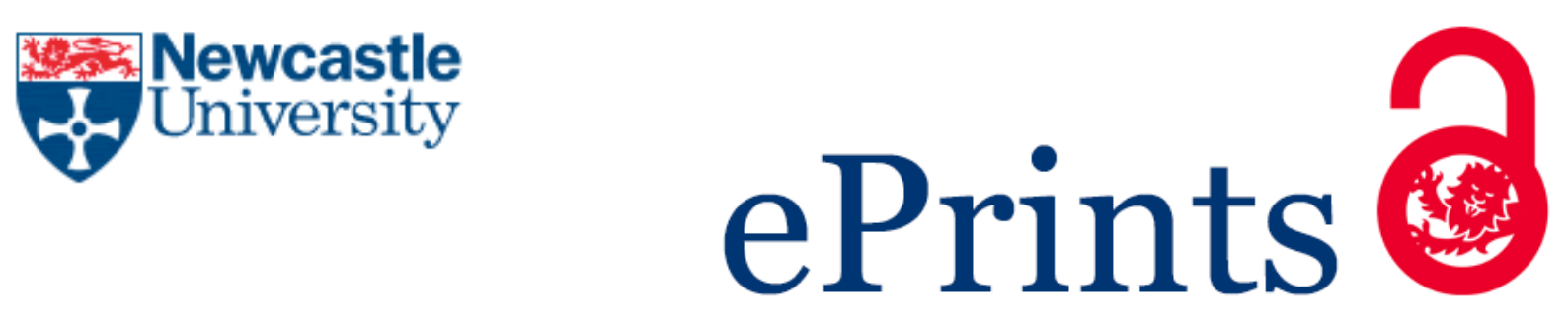

Sun W, Huang Y, Yin T, Wang J, Du R, Qiu J, Zhang Y, Wang Y, Chen J, Wang G. Effects of elemene on inhibiting proliferation of vascular smooth muscle cells and promoting reendothelialization at the stent implantation site. Biomaterials Science 2017, 5(6), 1144-1155.

\title{
Copyright:
}

CRoyal Society of Chemistry 2017

DOI link to article:

https://doi.org/10.1039/C7BM00190H

Date deposited:

$15 / 06 / 2017$

Embargo release date:

27 April 2018

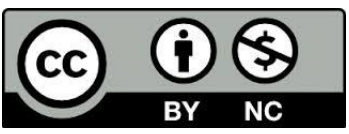

This work is licensed under a Creative Commons Attribution-NonCommercial 3.0 Unported License 


\section{Effects of elemene on inhibiting proliferation of vascular smooth muscle cells and promoting reendothelialization at the stent implantation site}

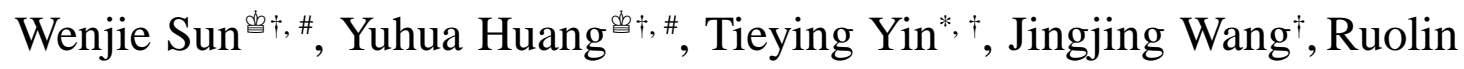

$\mathrm{Du}^{\dagger}$, Juhui Qiu', Yuan Zhang ${ }^{\ddagger}$, Yazhou Wang, ${ }^{* \dagger}$, Jinju Chen ${ }^{\S}$ Guixue Wang ${ }^{\dagger}$

${ }^{\dagger}$ Key Laboratory for Biorheological Science and Technology of Ministry of Education (Chongqing University), State and Local Joint Engineering Laboratory for Vascular Implants (Chongqing), Bioengineering College of Chongqing University, Chongqing 400030, China

‡Center of Cardiology, Chongqing Zhongshan Hospital, Chongqing 400013, China

§School of Mechanical \& System Engineering, Newcastle University, Newcastle Upon Tyne, UK

曾\# These authors contributed equally to this work.

*Corresponding Authors. Email address: tieying_yin@cqu.edu.cn (Tieying Yin);

yazhou_wang@cqu.edu.cn (Yazhou Wang)

Keywords: Restenosis; drug-eluting stents; elemene; smooth muscle cells; proliferation;

electrostatic spray. 


\section{Abstract}

Anticancer drugs as inhibitors of vascular smooth muscle cells (VSMCs) proliferation are commonly used in clinical treatment. This study aims to investigate how elemene affects the proliferation of VSMCs, the restenosis, and the reendothelialization after implantating the elemenecoated stents. VSMCs derived from rat aortic were tested the cell proliferation, cell cycle, migration, apoptosis, cytoskeletal protein F-action, intracellular $\mathrm{Ca}^{2+}$, IncRNA chip and gene expression of PCNA, P53, Cx43 when cultured with elemene. It was found that elemene can inhibit proliferation, induce apoptosis and block the connections between VSMCs in a dose-dependent manner. IncRNA chip analysis has revealed that there was a significant difference in the expression of 1417 genes and 34 signaling pathways. Elemene liposome membranes prepared by electrostatic spray could also inhibit the proliferation of VSMCs. In addition, after implanting the elemene-coated stent into rabbit iliac artery for 12 weeks, the surface of elemene-coated stents was fully covered with a layer of neointima and a few platelets. However, a large number of platelets aggregated and attached on the uncoated stents (control samples). In conclusion, Elemene could inhibit VSMCs proliferation in vitro which involved in the regulation of various signal transduction pathways and elemene-coated stents could promote endothelialization after stent implantation. Thus elemene has great potential for the clinical treatment of restenosis and reendothelialization.

\section{Introduction}


The development of drug-eluting stents (DES) has made s step change in reducing rates of restenosis after percutaneous coronary intervention. However, the rapid implementation of DES in different patients and complex lesions can introduce in-stent restenosis (ISR) ${ }^{1,2}$, which is problematic. ISR is a complicated process which contains many pathological changes, including intimal injury, thrombus formation, migration and proliferation of VSMCs and vascular remodeling. The abnormal proliferation and phenotypic change of VSMCs is one of the most important pathogenic mechanisms of neointimal hyperplasia and ISR ${ }^{3}$. After stent implantation, the intimal was damaged and a number of cytokines and growth factors were synthesized and secreted. The local mechanical environment of cells also changed, which would affect the intracellular signalling that controls VSMCs's migration, proliferation and secretion of extracellular matrix, and cell phenotype. This consequently leads to the formation of neointimal hyperplasia and ISR ${ }^{4-7}$. The occurrence and molecular biological mechanism of VSMCs proliferation and endothelial regeneration after vascular injury are similar to cancer development with enhanced cell proliferation and reduced apoptosis ${ }^{8}$. As inhibitors of VSMCs proliferation, anticancer drugs are commonly used in clinical treatment ${ }^{9,10}$.

Elemene (1-methyl-1-vinyl-2, 4-diisopropenyl-cyclohexane) is an effective antitumor drug which can reduce tumor cells' mitosis, induce tumor cell apoptosis, block tumor cells into the $\mathrm{G}_{2} / \mathrm{M}$ phase from the S phase, inhibit tumor angiogenesis and so on ${ }^{11}$. Elemene at low concentration can inhibit neointimal hyperplasia in the rat carotid artery after balloon injury while protecting vascular endothelial cell from injury, therefore, it promotes vascular endothelial cells proliferation ${ }^{12}$. It is suggested that elemene has potential for treating atherosclerosis and restenosis ${ }^{13}$. Elemene also has the potential for inhibiting thrombus formation ${ }^{13}$, angiogenesis ${ }^{14}$, VSMCs proliferation and migration as well as intimal hyperplasia ${ }^{12}$. In addition, it also protects VSMCs against oxidative 
injuries ${ }^{15}$ and inflammation ${ }^{16}$. The study aims to investigate the influence of elemene on VSMCs proliferation and gene expression under both static and cyclic stretch. Intimal hyperplasia, thrombosis, and reendothelialization are investigated after elemene-coated stents implant into the rabbit iliac artery. It is anticipated that this study could pave the way for adopting elemene for cardiovascular interventions.

\section{Materials and methods}

\section{Animals and materials}

Fifteen inbred strain New Zealand White male rabbits (2.6 to $3.5 \mathrm{~kg}$ ) and ten male Sprague-Dawley rats were purchased from the Experimental Animal Center of Third Military Medical University, Chongqing, China. After 1 week of normal feeding in the standard environment, the rabbits were randomly divided into two groups, i.e., implanted elemene-coated $(n=11)$ and bare $(n=9)$ stents group. All rabbits were fed normally pre- and post-stent implantation without feeding any medicine. The experimental protocol was in accordance with the "Principles of Laboratory Animal Care" (formulated by the National Society for Medical Research) and the "Guide for the Care and Use of Laboratory Animals” published by the US National Institutes of Health (NIH Publication No. 8523, revised 1996). Ethics approval was granted by the Third Military Medical University ethics review board.

Twenty-five 316L stainless steel stents $(1.4 \mathrm{~mm} \times 17 \mathrm{~mm})$, which could be expanded to $3 \mathrm{~mm}$ were purchased from MeiZhongShuangHe Medical Device Inc., Beijing, China. PLGA polymer was obtained from Sigma Inc. (St. Louis, MO, USA). The antibody was dissolved in a sodium phosphate buffer (0.15 m/L NaCl and $0.001 \%$ Tween-80, $\mathrm{pH} 7.2)$ at a concentration of $2.0 \mathrm{mg} / \mathrm{mL}$. 
Elemene was donated by Dalian Jin-gang Pharmaceutical Co. ( 5 mg/mL, Dalian, China).

\section{Cell isolation and culture}

VSMCs were derived from rat aorta following the same protocol as previously described ${ }^{17}$. The cells were cultured in DMEM/F12 (Hyclone, Beijing, China) and FBS (Hyclone, Beijing, China) with $\mathrm{P} / \mathrm{S}$. Then immunofluorescence staining of $\alpha$-SMA (Boster, Wuhan, China) was used to ensure good imaging quality of VSMCs. VSMCs between passages 3 to 8 are used in all experiments.

\section{Proliferation, cyclic and apoptosis analysis}

VSMCs at a density of $1 \times 10^{5} / \mathrm{mL}$ were cultured for $24 \mathrm{~h}$ and were then exposed to elemene at various concentrations $(6.25 \mu \mathrm{g} / \mathrm{mL}, 12.5 \mu \mathrm{g} / \mathrm{mL}, 25 \mu \mathrm{g} / \mathrm{mL}, 50 \mu \mathrm{g} / \mathrm{mL}$ and $100 \mu \mathrm{g} / \mathrm{mL})$ and elemene liposome membranes with varied elemene surface concentrations ( $5 \mu \mathrm{g} / \mathrm{mm}^{2}, 10 \mu \mathrm{g} / \mathrm{mm}^{2}$, $15 \mu \mathrm{g} / \mathrm{mm}^{2}$ ) for four different time intervals ( $24 \mathrm{~h}, 48 \mathrm{~h}, 72 \mathrm{~h}$ and $96 \mathrm{~h}$ ). The proliferation of cells was measured by cell counting and recorded by both stereo microscope and fluorescence microscopy. Cell cycle and apoptosis were analyzed by PI staining flow cytometry and Annexin VFITC/PI (Beyotime, Shanghai, China) double staining flow cytometry.

\section{Migration of VSMCs}

The migration of VSMCs was measured using the scratch wound healing assay ${ }^{18}$. The VSMCs were treated with different concentrations $(6.25 \mu \mathrm{g} / \mathrm{mL}, 12.5 \mu \mathrm{g} / \mathrm{mL}, 25 \mu \mathrm{g} / \mathrm{mL}, 50 \mu \mathrm{g} / \mathrm{mL}$ and 100 $\mu \mathrm{g} / \mathrm{mL}$ ) of elemene for $24 \mathrm{~h}$. The cell migration pictures were collected at $0 \mathrm{~h}, 24 \mathrm{~h}, 48 \mathrm{~h}$ and $72 \mathrm{~h}$ under phase contrast microscope. The commercial image processing software (IMAGE-PRO PLUS) was used to measure cell migration distance.

Another method to detect cell migration was to use the transwell migration assay as previously described ${ }^{19}$. VSMCs $\left(5 \times 10^{4}\right.$ cells/chamber) were seeded into the upper chamber (Boyden). Each 
well was separated into two chambers by a membrane with $8 \mu \mathrm{m}$ pores. Chemotaxis was achieved in the presence of $100 \%$ FBS in the bottom chamber. After $8 \mathrm{~h}$, the transwell chambers were rinsed in PBS, and the cells at the bottom of the transwell membrane were fixed with $4 \%$ paraformaldehyde (Boster, Wuhan, China) at $37^{\circ} \mathrm{C}$ for $15 \mathrm{~min}$, and then rinsed with PBS. The migrated cells were counted manually using a phase contrast microscope. The migration was quantified by the analysis of at least 10 random fields per filter.

\section{Immunofluorescence of intracellular F-action and $\mathrm{Ca}^{2+}$}

After treating with elemene $(25 \mu \mathrm{g} / \mathrm{mL})$ for $24 \mathrm{~h}$, VSMCs were fixed in $4 \%$ paraformaldehyde and then incubated with $0.1 \%$ Triton X-100 for 10 min, blocked with 1\% BSA (Boster, Wuhan, China) for 30 min. The F-actin was directly stained with FITC-Phalloidin (1:200 dilution in 1\% BSA) (Sigma, CA, USA) for $1 \mathrm{~h}$, and the cell nuclei were counterstained with DAPI (Boster Institute of Biotechnology, Wuhan, China) for $5 \mathrm{~min}$. The unbound molecules were washed away and the cells were assessed using a fluorescence microscope (Olympus BX81, Japan).

\section{Cyclic strain}

For cyclic strain studies, VSMCs were seeded into fibronectin-coated 6-well Bioflex plates (Flexcell International Corp, Burlington, NC). When cells have reached 80\% confluence they were treated with $100 \mu \mathrm{g} / \mathrm{mL}$ elemene for $2 \mathrm{~h}$. Then the culture medium without serum was added, and a Flexercell Tension Plus FX-4000T system was used to apply a physiological level of cyclic strain ( $5 \%$ strain, $1 \mathrm{~Hz}$ ) for $12 \mathrm{~h}$. After being subjected to strain, the VSMCs were harvested for IncRNA chips and western blotting assay.

\section{IncRNA chips and Western Blotting}

The total mRNA was extracted, and cDNA was produced via reverse transcription. The Cy3 
fluorescence dye was used for marking the cDNA probe. Hybrid scan and analysis with the expression arrays were carried out by IncRNA chip (KangChen Bio-tech, China).

Cells were dissolved in lysis buffer containing $0.5 \%$ protease inhibitor mixture and kept at $37^{\circ} \mathrm{C}$ for 30 min. The protein concentration of the lysate was determined with a Protein Assay Kit. Protein was fixed with loading buffer and kept at $-20^{\circ} \mathrm{C}$. The entire protein samples from a total cell lysate were separated by SDS-PAGE, transferred to immobilon membranes, and incubated with anti-rat antibody. After washing and incubation with horseradish peroxidase-linked anti-rabbit IgG, immunoreactive proteins were visualized with an ECL Plus detection system and a Versa Doc ND2000 molecular imager system.

\section{Elemene liposome and its characterization}

Elemene, lecithin, and cholesterol were mixed with the ratio of 1:8:2, and completely dissolved by adding anhydrous ethanol to form an oil phase. $10 \mathrm{~mL}$ phosphate buffer containing 0.05\% PEG 2000 was placed into a three-necked bottle. The oil phase was then injected into the water phase at a slow constant speed by using a syringe needle, in a $50{ }^{\circ} \mathrm{C}$ water bath with $30 \mathrm{rpm}$. After 2 hours, ethanol was removed and the mixture was filtrated with $0.22 \mu \mathrm{m}$ microporous membrane to extract the elemene liposomes. The particle size and zeta potential of the elemene liposomes were measured by dynamic laser light scattering (Malvern Zetasizer Nano ZS90, Malvern Instruments Ltd, UK).

\section{Elemene liposome membranes and elemene coated stents by electrostatic spray}

Elemene liposomes were then used as the inner liquid of electronic injection, while PLGA (10 $\mathrm{mg} / \mathrm{mL})$ was the outer solution. Different elemene liposome membranes $\left(5 \mu \mathrm{g} / \mathrm{mm}^{2}, 10 \mu \mathrm{g} / \mathrm{mm}^{2}\right.$, $15 \mu \mathrm{g} / \mathrm{mm}^{2}$ ) were prepared by adjusting the electrostatic spray parameters, such as voltage, current velocity, spray distance, and spray time. With 316L stainless steel vascular stent as a receiver, 
elemene coated stents were then obtained (Supplementary Figure S1). Elemene liposomes coating on the stent surface was analysed by scanning electron microscope and stereomicroscope.

\section{The release rate of elemene liposomes membranes by HPLC}

The PLGA was used as binder matrix for elemene liposome membranes (ELM) and the elemene injection membranes (EIM). Both membranes (i.e. PLGA/ELM mixture and PLGA/EIM) were placed in $1 \mathrm{~mL}$ PBS solution at the temperature of $37^{\circ} \mathrm{C}$ wet box with $60 \mathrm{rpm}$. The membranes were retrieved from the solution at various time interval (20 min-28days). The retrieved membranes were soaked in $1 \mathrm{~mL}$ ethanol $2 \mathrm{~h}$ to dissolve residual elemene, followed by oscillating demulsification and membrane filtration. They were then injected into liquid chromatography special bottle and sealed at $4{ }^{\circ} \mathrm{C}$. Residual elemene was measured by HPLC, which enables us to analyse elemene drug release rate.

\section{In vivo implantation procedures}

The rabbits were anesthetized with pentobarbital sodium $(50 \mathrm{mg} / \mathrm{mL}, 30 \mathrm{mg} / \mathrm{kg}$ ) through the ear vein. The stents mounted on a balloon catheter were implanted into the iliac artery from the left carotid artery through a 5F sheath introducer (Terumo, Japan) under fluoroscopy using a guide wire (Cook, USA). The stent deployment conditions are less than 1.2:1 (stent: artery) ratio by quantitative coronary angiography (QCA). The balloon was inflated at a pressure of $10 \mathrm{~atm}$ for 30 s, deflated, and then slowly withdrawn, leaving the stent in place. QCA was performed before implantation and explantation to determine the diameter of the vessel lumen. Fifteen milliliters of heparin ( $250 \mathrm{~mL} 0.9 \% \mathrm{NaCl}+6000 \mathrm{U})$ were administered during the entire angiography. One bare stent or elemene-coated stent was implanted into a single iliac artery and was kept in place for 12 weeks. The animals received no anticoagulant or antiplatelet therapy post operation. 


\section{Electron microscope}

After 12 weeks, the stent implanted arterial segments were removed and washed in heparin solution $(1000 \mathrm{~mL} 0.9 \% \mathrm{NaCl}+6000 \mathrm{U})$ and PBS, prior to sectioning. The specimens were post-fixed in a 2.5\% isotonic buffered glutaraldehyde and coated with gold. After that, these samples were examined by scanning electron microscope (Model 1000 B, Amray, Bedford, MA, USA).

\section{Statistical analysis}

The statistical analysis was done by one-way or two-way ANOVA using SPSS. The differences among the experimental groups were considered statistically significant when $\mathrm{p}<0.05$. Unless indicated, the values were expressed as mean $\pm \mathrm{SD}$.

\section{Results}

\section{Elemene inhibits the proliferation of VSMCs and induces apoptosis}

With the increase of elemene concentration, the density of VSMCs decreased gradually and the connections between cells were broken and inhibited (Figure 1A, B, C). When the concentration was over $12.5 \mu \mathrm{g} / \mathrm{mL}(p<0.05)$, the synapses increased and the spreading area was significantly inhibited. When the concentration reached $100 \mu \mathrm{g} / \mathrm{mL}$, the number of VSMCs did not increase at all. One possible mechanism for this was the increase in cell apoptosis. With the increase of elemene concentration, the cell apoptosis rate increased gradually. The apoptosis rate for the group treated by $25 \mu \mathrm{g} / \mathrm{mL}$ elemene was twice as the untreated control group (Figure 1D). On the other hand, flow cytometry indicated that elemene could keep VSMCs in the stages of $S$ and $G_{2}$ and thus inhibit the proliferation After $25 \mu \mathrm{g} / \mathrm{mL}$ elemene treatment for $24 \mathrm{~h}$, cells in $\mathrm{G}_{1}$ phase, $\mathrm{S}$ phase and $\mathrm{G}_{2}$ phase were $74.92 \%, 19.97 \%$, and $5.11 \%$, respectively. Whilst, in untreated control group, the 
corresponding relative cell populations were $83.45 \%, 12.80 \%$, and 3.74\%, respectively. (Figure 1E).

The $\mathrm{Ca}^{2+} / \mathrm{calmodulin}$ could be used to adjust the gap junction for intercellular communication, which will then affect cell proliferation, apoptosis, and differentiation. The level of $\left[\mathrm{Ca}^{2+}\right]$ in quiescent cells was stable. However, after the addition of $25 \mu \mathrm{g} / \mathrm{mL}$ elemene, the level of [ $\left.\mathrm{Ca}^{2+}\right]$ in the cells began to rise in 10 seconds and to reach the peak for about 20 seconds, and its peak value is nearly as twice as the quiescent state. Then in the following 10 seconds, it drops to that for quiescent cells and goes down by $17 \%$ slowly (Figure 1F). 

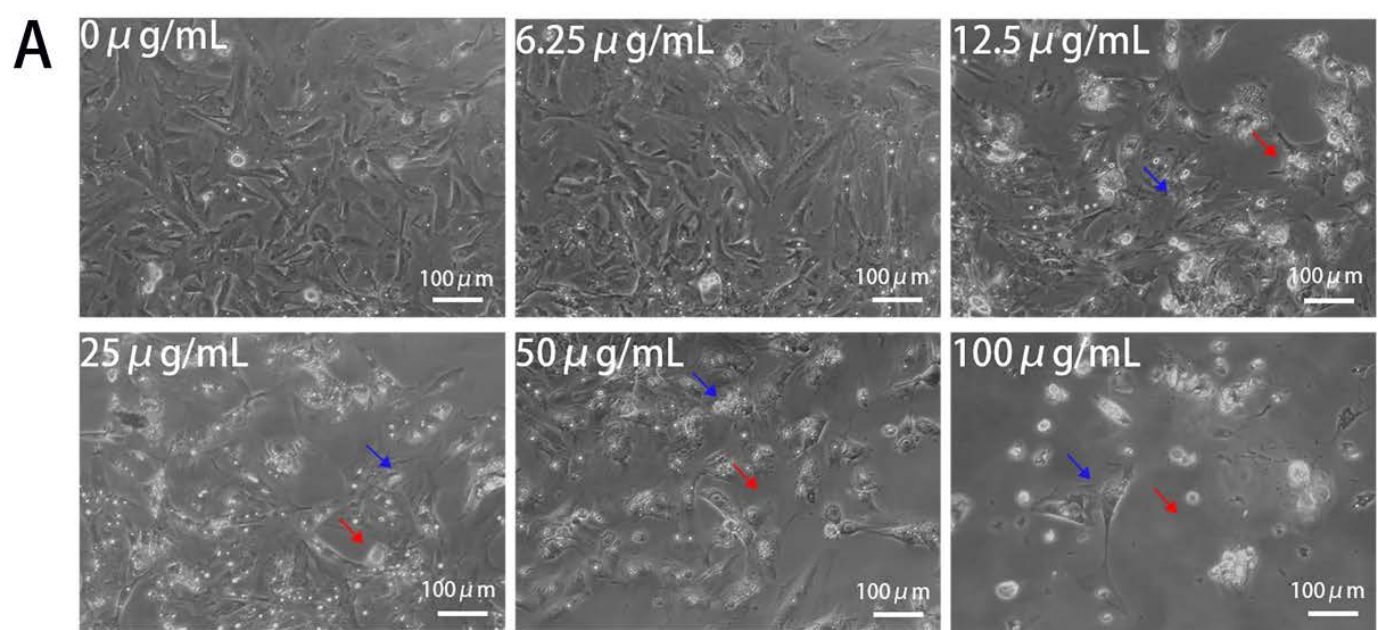

B
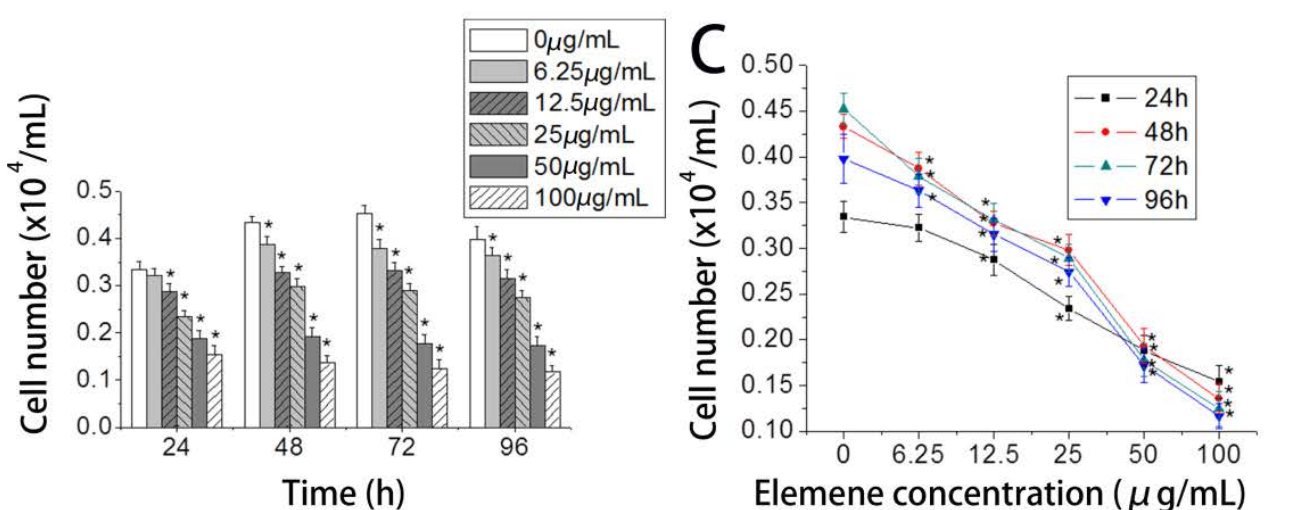

$\mathrm{D}$
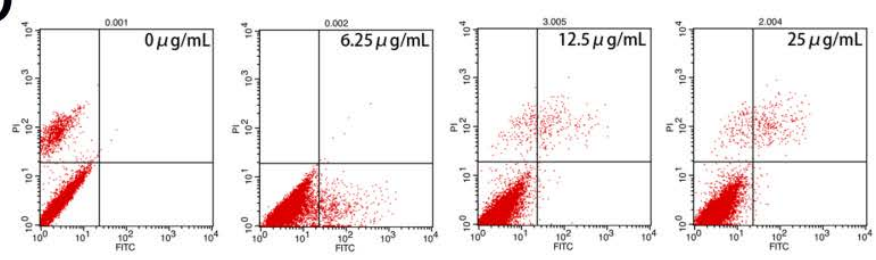

Elemene concentration $(\mu \mathrm{g} / \mathrm{mL})$
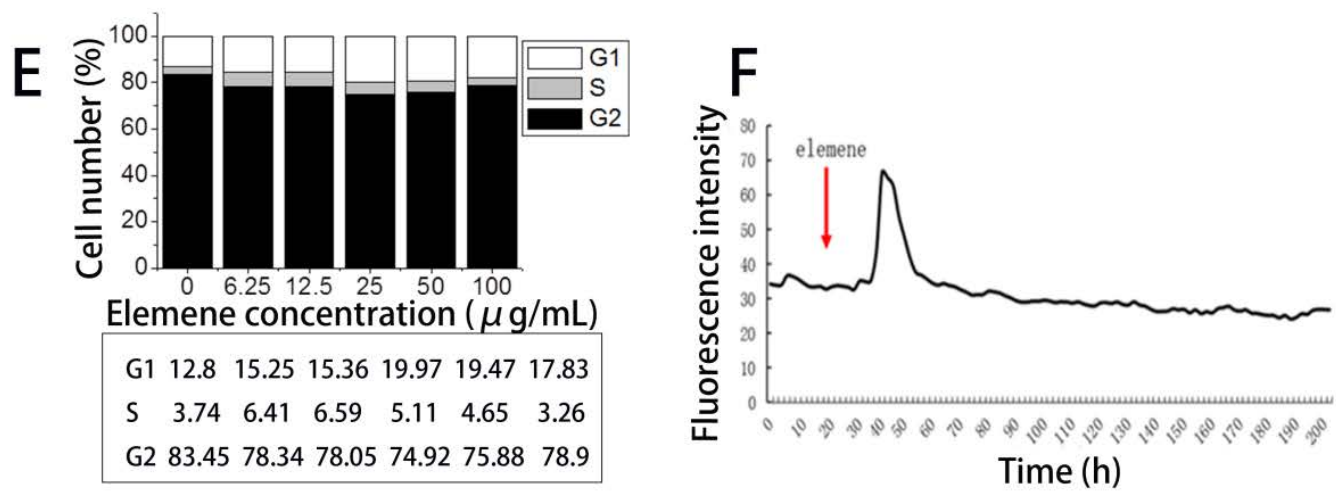

Figure 1. Effect of elemene on VSMCs proliferation, cell cycle and apoptosis.

(A) Phase contrast microscopic images of VSMCs $(100 \times)$ cultured with $\beta$-elemene for $48 \mathrm{~h}$ at different concentrations. The red arrow indicates the connection between the vascular smooth muscle cells was interrupted. Blue arrow indicates the cell synapse was increase. (B, C) The VSMCs numbers cultured with elemene for $24 \mathrm{~h}, 48 \mathrm{~h}, 72 \mathrm{~h}, 96 \mathrm{~h}$ at the different concentrations. The data 
are expressed as mean \pm SD from 5 separate samples. ( ${ }^{*} \mathrm{P}<0.05$ vs. no elemene treated). (D) The apoptosis of VSMCs after treatment with elemene at different concentration. With the increase of elemene concentration, the cell apoptosis rate increase gradually. The apoptosis rate of the group treated by $25 \mu \mathrm{g} / \mathrm{mL}$ elemene is double compared with the control. (E) Cell cycle of VSMCs after incubated in DMEM/F12 with 20 \%FBS for $24 \mathrm{~h}$ with elemene at different concentration. Elemene can inhibit the proliferation of VSMCs in the stages of $S$ and $\mathrm{G}_{2}$ by flow cytometry, the percentage of the VSMCs is increased by $8.54 \%$ compared with the untreated group. (F) $\mathrm{Ca}^{2+}$ in VSMCs cultured with $25 \mu \mathrm{g} / \mathrm{mL} \beta$-elemene for $24 \mathrm{~h}$. The level of intracellular $\left[\mathrm{Ca}^{2+}\right]$ rise up considerably after 20 seconds, and the rate of increase is twice as high as the quiescent state at 50 seconds. Then it declines by $17 \%$ about 80 seconds later.

\section{Elemene inhibits the migration of VSMCs}

Another key mechanism of neointima hyperplasia was the migration of VSMCs. Scratch wound healing assay revealed that elemene significantly reduced the migration of VSMCs in a dosedependent manner (Figure 2A, B). The migrated VSMCs was measured by transwell migration assay. In demonstrated that elemene significantly inhibited the migration of VSMCs at centrations of $12.5 \mu \mathrm{g} / \mathrm{mL}, 25 \mu \mathrm{g} / \mathrm{mL}, 50 \mu \mathrm{g} / \mathrm{mL}(\mathrm{p}<0.05)$ and $100 \mu \mathrm{g} / \mathrm{mL}$ ( $\mathrm{p}<0.01)$ compared with the untreated control (Figure 2C).

At a concentration of $25 \mu \mathrm{g} / \mathrm{mL}$, elemene significantly affected the number and morphology of VSMCs after co-culture with VSMCs for $24 \mathrm{~h}$. Cytoskeleton filaments of the elemene treated group were thicker than the control group and cell morphology was elongated (Figure 2D). 

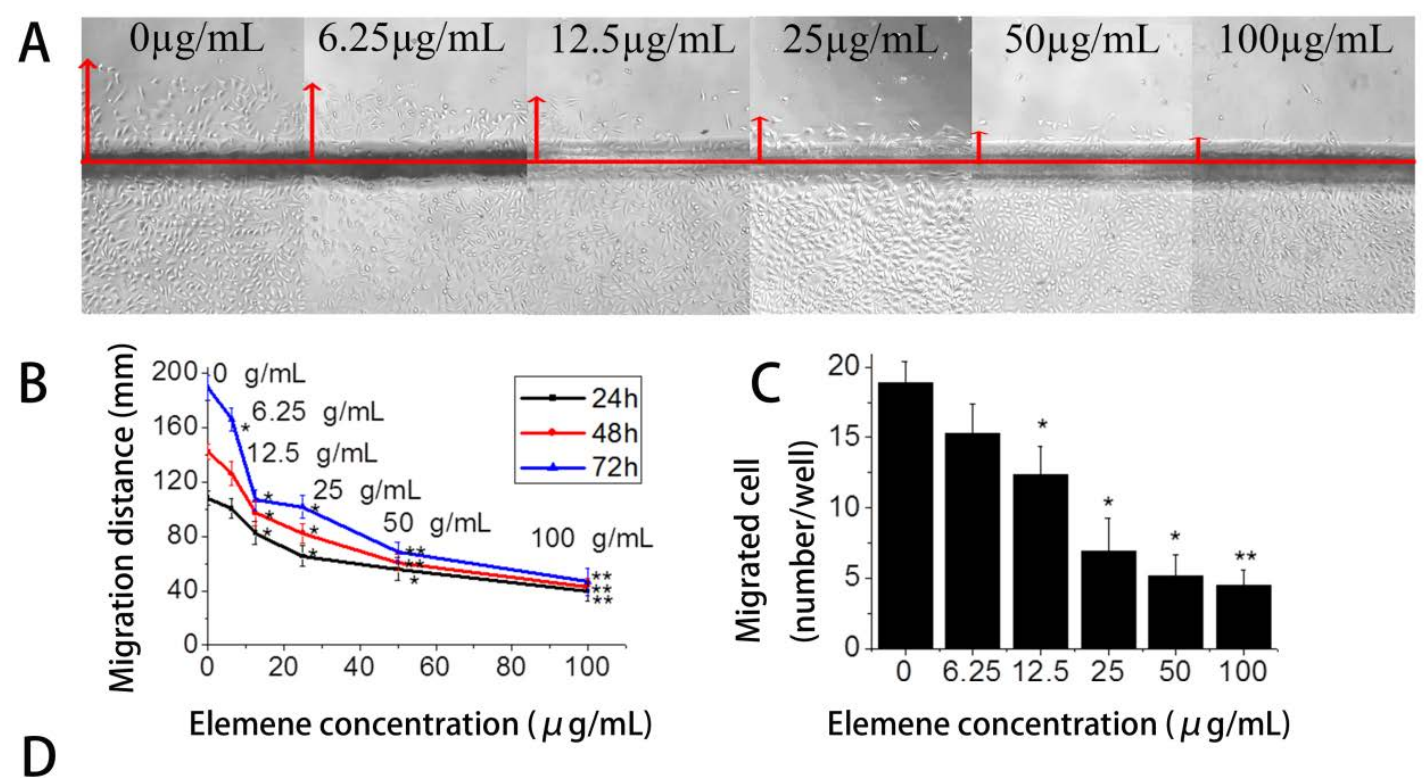

Elemene concentration $(\mu \mathrm{g} / \mathrm{mL})$
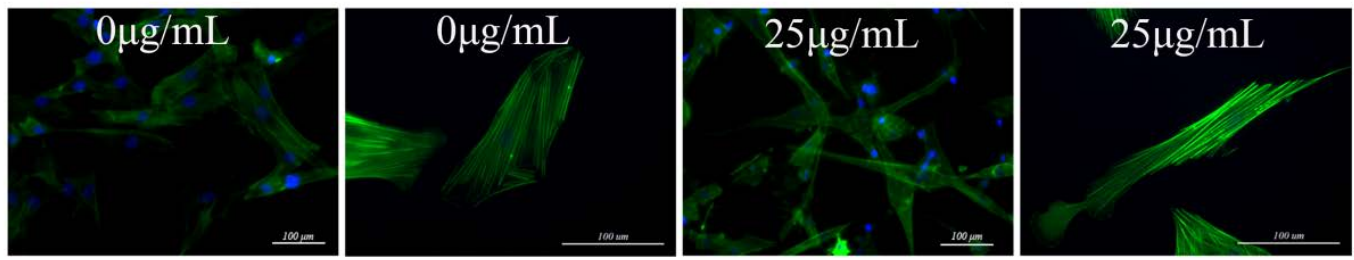

Figure 2. Migration of VSMCs after co-cultured with elemene.

(A) The migration distance decrease with the increase of elemene concentration, after co-cultured for $72 \mathrm{~h}$. (B) The migration distance have significant differences when the concentration greater than $12.5 \mu \mathrm{g} / \mathrm{mL}$. (*, $p<0.05 ;{ }^{* *}, p<0.01$ ) (C) Elemene can also inhibit the number of VSMCs induced by $100 \%$ FBS migrate from upper chamber to the lower one through the transwell membrane filter. (D) F-actin in VSMCs cultured with $25 \mu \mathrm{g} / \mathrm{mL}$ elemene for $24 \mathrm{~h}(\times 100$ and $\times 200)$. The cells treated with elemene are arranged in a disorder and sparsely way, with narrowed shape and decreased spreading area compared with controls. Cytoskeleton filaments of the elemene treated group are thicker than the control group.

\section{Effects of elemene on VSMCs under cyclic strain}

Pathological cyclic strain can enable VSMCs to transfer from contractile phenotype to synthetic phenotype. In the selected $4 \times 44 \mathrm{k}$ gene expression profiles, 1417 gene expressions show differences (over twice). Among which, the expression of 699 genes go up and 718 genes decrease. Among 
these 1417 gene expressions, 34 signaling pathways were involved, including PPAR, MAPK, AKT and ERK1/2 (Table 1, Table 2). So we investigated the PCNA, P53, Cx43 expression. It seems that elemene affected gene expression in similar way whether under static culture or cyclic strain. Under cyclic strain, elemene gave rise to the expression of P53 and inhibited that of PCNA and Cx43 (Figure 3).
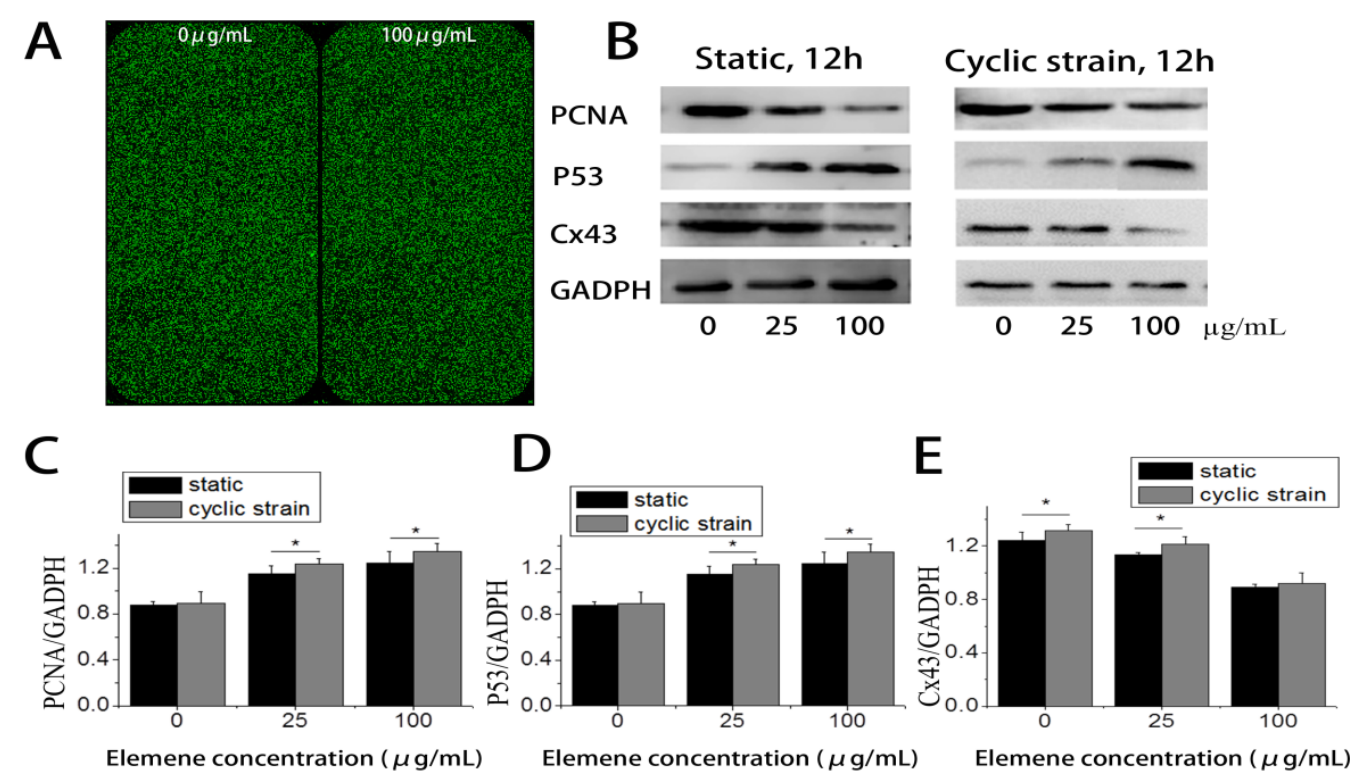

Figure 3. Effects of elemene on VSMCs under cyclic strain.

(A) IncRNA chip scan of VSMCs and VSMCs which co-cultured with $100 \mu \mathrm{g} / \mathrm{mL}$ elemene for $2 \mathrm{~h}$ stretching for 12 h. (B) Representative immunoblots of PCNA, P53, Cx43 and GADPH expression in VSMCs with different concentrations of elemene to stimulate for $12 \mathrm{~h}$. The quantitative analysis of (C) PCNA/GADPH, (D) P53/GADPH, (E) Cx43/GADPH in VSMCs stretching for $12 \mathrm{~h}$ after treated with different concentration of elemene for $2 \mathrm{~h}(\mathrm{n}=3)$. Under the static and cyclic stretches, elemene can rise the expression of P53 and inhibit that of PCNA and Cx43.

Table.1 Pathway analysis up differentially expressed gene list

Pathway

ID
Definition

\section{Genes}




\begin{tabular}{|c|c|c|}
\hline rno05213 & $\begin{array}{l}\text { Endometrial cancer - } \\
\text { Rattus norvegicus (rat) }\end{array}$ & AKT1//AKT2//APC2//AXIN2//CTNNB1//MAPK1 \\
\hline rno03440 & $\begin{array}{l}\text { Homologous } \\
\text { recombination - Rattus } \\
\text { norvegicus (rat) }\end{array}$ & MRE11A//POLD1//RAD52//RPA1 \\
\hline rno05142 & $\begin{array}{l}\text { Chagas disease } \\
\text { (American } \\
\text { trypanosomiasis) - } \\
\text { Rattus norvegicus (rat) }\end{array}$ & $\begin{array}{l}\text { AKT1//AKT2//FAS//GNA15//GNAI1//IKBKG//MAP } \\
\text { K1//TLR4 }\end{array}$ \\
\hline rno05160 & $\begin{array}{l}\text { Hepatitis C - Rattus } \\
\text { norvegicus (rat) }\end{array}$ & $\begin{array}{l}\text { AKT1//AKT2//CD81//CLDN22//EIF2AK4//IKBKG// } \\
\text { MAPK1//SCARB1//SOCS3 }\end{array}$ \\
\hline rno04012 & $\begin{array}{l}\text { ErbB signaling pathway } \\
\text { - Rattus norvegicus (rat) }\end{array}$ & ABL2//AKT1//AKT2//AREG//MAPK1//PAK3//TGFA \\
\hline rno05145 & $\begin{array}{l}\text { Toxoplasmosis - Rattus } \\
\text { norvegicus (rat) }\end{array}$ & $\begin{array}{l}\text { AKT1//AKT2//GNAI1//IKBKG//MAPK1//PLA2G4B// } \\
\text { RT1-HA//TLR4//XIAP }\end{array}$ \\
\hline rno05212 & $\begin{array}{l}\text { Pancreatic cancer - } \\
\text { Rattus norvegicus (rat) }\end{array}$ & AKT1//AKT2//ARHGEF6//IKBKG//MAPK1//TGFA \\
\hline rno05210 & $\begin{array}{l}\text { Colorectal cancer - } \\
\text { Rattus norvegicus (rat) }\end{array}$ & AKT1//AKT2//APC2//AXIN2//CTNNB1//MAPK1 \\
\hline rno05223 & $\begin{array}{l}\text { Non-small cell lung } \\
\text { cancer - Rattus } \\
\text { norvegicus (rat) }\end{array}$ & AKT1//AKT2//MAPK1//RASSF5//TGFA \\
\hline
\end{tabular}




\begin{tabular}{|c|c|c|}
\hline rno04120 & $\begin{array}{l}\text { Ubiquitin mediated } \\
\text { proteolysis - Rattus } \\
\text { norvegicus (rat) }\end{array}$ & $\begin{array}{l}\text { BRCA1//FBXO4//HERC3//KLHL9//PPIL2//RHOBTB } \\
\text { 2//SOCS3//XIAP }\end{array}$ \\
\hline rno00232 & $\begin{array}{l}\text { Caffeine metabolism - } \\
\text { Rattus norvegicus (rat) }\end{array}$ & CYP2A2//NAT2 \\
\hline rno05215 & $\begin{array}{l}\text { Prostate cancer - Rattus } \\
\text { norvegicus (rat) }\end{array}$ & AKT1//AKT2//CTNNB1//IKBKG//MAPK1//TGFA \\
\hline rno05140 & $\begin{array}{l}\text { Leishmaniasis - Rattus } \\
\text { norvegicus (rat) }\end{array}$ & FCGR2A//MAPK1//PTGS2//RT1-HA//TLR4 \\
\hline rno04920 & $\begin{array}{l}\text { Adipocytokine } \\
\text { signaling pathway - } \\
\text { Rattus norvegicus (rat) }\end{array}$ & AKT1//AKT2//CPT1A//IKBKG//SOCS3 \\
\hline rno05211 & $\begin{array}{l}\text { Renal cell carcinoma - } \\
\text { Rattus norvegicus (rat) }\end{array}$ & AKT1//AKT2//MAPK1//PAK3//TGFA \\
\hline rno00071 & $\begin{array}{l}\text { Fatty acid metabolism - } \\
\text { Rattus norvegicus (rat) }\end{array}$ & ACADSB//CPT1A//CYP4A8//EHHADH \\
\hline rno04380 & $\begin{array}{l}\text { Osteoclast } \\
\text { differentiation - Rattus } \\
\text { norvegicus (rat) }\end{array}$ & $\begin{array}{l}\text { AKT1//AKT2//FCGR2A//IKBKG//MAPK1//SOCS3// } \\
\text { TNFRSF11B }\end{array}$ \\
\hline rno05200 & $\begin{array}{l}\text { Pathways in cancer - } \\
\text { Rattus norvegicus (rat) }\end{array}$ & $\begin{array}{l}\text { AKT1//AKT2//APC2//AXIN2//CTNNB1//FAS//IKBK } \\
\text { G//KITLG//MAPK1//PTGS2//RASSF5//TGFA//WNT } \\
\text { 4//XIAP }\end{array}$ \\
\hline
\end{tabular}




\begin{tabular}{|c|c|c|}
\hline rno04062 & $\begin{array}{l}\text { Chemokine signaling } \\
\text { pathway - Rattus } \\
\text { norvegicus (rat) }\end{array}$ & $\begin{array}{l}\text { AKT1//AKT2//CCL2//CCL7//GNAI1//GNGT2//IKBK } \\
\text { G//IL8RB//MAPK1 }\end{array}$ \\
\hline rno04370 & $\begin{array}{l}\text { VEGF signaling } \\
\text { pathway - Rattus } \\
\text { norvegicus (rat) }\end{array}$ & AKT1//AKT2//MAPK1//PLA2G4B//PTGS2 \\
\hline rno04662 & $\begin{array}{l}\text { B cell receptor } \\
\text { signaling pathway - } \\
\text { Rattus norvegicus (rat) }\end{array}$ & AKT1//AKT2//CD81//IKBKG//MAPK1 \\
\hline rno04010 & $\begin{array}{l}\text { MAPK signaling } \\
\text { pathway - Rattus } \\
\text { norvegicus (rat) }\end{array}$ & $\begin{array}{l}\text { AKT1//AKT2//BDNF//CACNB4//DUSP10//FAS//IKB } \\
\text { KG//MAP3K13//MAPK1//PLA2G4B//PTPN5//TAOK } \\
2\end{array}$ \\
\hline rno00140 & $\begin{array}{l}\text { Steroid hormone } \\
\text { biosynthesis - Rattus } \\
\text { norvegicus (rat) }\end{array}$ & COMT//CYP1A1//HSD17B6//HSD3B5 \\
\hline rno05217 & $\begin{array}{l}\text { Basal cell carcinoma - } \\
\text { Rattus norvegicus (rat) }\end{array}$ & APC2//AXIN2//CTNNB1//WNT4 \\
\hline
\end{tabular}

"Pathway ID" stands for Pathway identifiers used in KEGG; "Definition" stands for the definition of the Pathway ID; "GENES" stands for the DE genes associated with the Pathway ID.

Table.2 Pathway analysis down differentially expressed gene list

PathwayID Definition Genes




\begin{tabular}{|c|c|c|}
\hline rno00100 & $\begin{array}{l}\text { Steroid biosynthesis - } \\
\text { Rattus norvegicus (rat) }\end{array}$ & CEL//DHCR7//EBP//HSD17B7//NSDHL \\
\hline rno00900 & $\begin{array}{l}\text { Terpenoid backbone } \\
\text { biosynthesis - Rattus } \\
\text { norvegicus (rat) }\end{array}$ & ACAT3//HMGCR//HMGCS1//MVD \\
\hline rno00640 & $\begin{array}{l}\text { Propanoate metabolism } \\
\text { - Rattus norvegicus (rat) }\end{array}$ & ACACA//ACAT3//ACSS2//LDHAL6B \\
\hline rno00620 & $\begin{array}{l}\text { Pyruvate metabolism - } \\
\text { Rattus norvegicus (rat) }\end{array}$ & ACACA//ACAT3//ACSS2//LDHAL6B \\
\hline rno03320 & $\begin{array}{l}\text { PPAR signaling } \\
\text { pathway - Rattus } \\
\text { norvegicus (rat) }\end{array}$ & ACSL3//ANGPTL4//SCD//SLC27A2//SLC27A5 \\
\hline rno04640 & $\begin{array}{l}\text { Hematopoietic cell } \\
\text { lineage - Rattus } \\
\text { norvegicus (rat) }\end{array}$ & CD5//GP5//IL1R1//IL9R//MS4A1 \\
\hline rno00650 & $\begin{array}{l}\text { Butanoate metabolism - } \\
\text { Rattus norvegicus (rat) }\end{array}$ & ACAT3//ACSM2//HMGCS1 \\
\hline rno00072 & $\begin{array}{l}\text { Synthesis and } \\
\text { degradation of ketone } \\
\text { bodies - Rattus } \\
\text { norvegicus (rat) }\end{array}$ & ACAT3//HMGCS1 \\
\hline rno05416 & $\begin{array}{l}\text { Viral myocarditis - } \\
\text { Rattus norvegicus (rat) }\end{array}$ & MYH1//MYH2//MYH7//RT1-S3//SGCA \\
\hline rno00630 & $\begin{array}{l}\text { Glyoxylate and } \\
\text { dicarboxylate } \\
\text { metabolism - Rattus } \\
\text { norvegicus (rat) }\end{array}$ & АСАТЗ//ACO2 \\
\hline
\end{tabular}

"Pathway ID" stands for Pathway identifiers used in KEGG; "Definition" stands for the definition of the Pathway ID; "GENES" stands for the DE genes associated with the Pathway ID. 


\section{Elemene liposome and the sustained-release of its membranes}

Electrostatic spray enables good particle size distribution and morphology, as shown in Figure 4A.

The standard curve of elemene liposome was obtained through the HPLC assay, which shows a linear relationship between drug release and time in the range of $5 \mu \mathrm{g} / \mathrm{mL}$ to $25 \mu \mathrm{g} / \mathrm{mL}$. (Figure 4B). $40 \%$ of elemene was released from elemene injection membranes within $1 \mathrm{~h}$ and another $46 \%$ released in the following 28 days. In contrast, in the elemene liposome membrane, only $28 \%$ was released at the first $1 \mathrm{~h}$ and more than $20 \%$ retained within it after 28 days. $50 \%$ of elemene was released from elemene injection membranes within $4 \mathrm{~h}$ and reached plateau in 2 days, while liposome membrane released 50\% after 1 day and gradually reached $80 \%$ in the next (Figure 4C). 

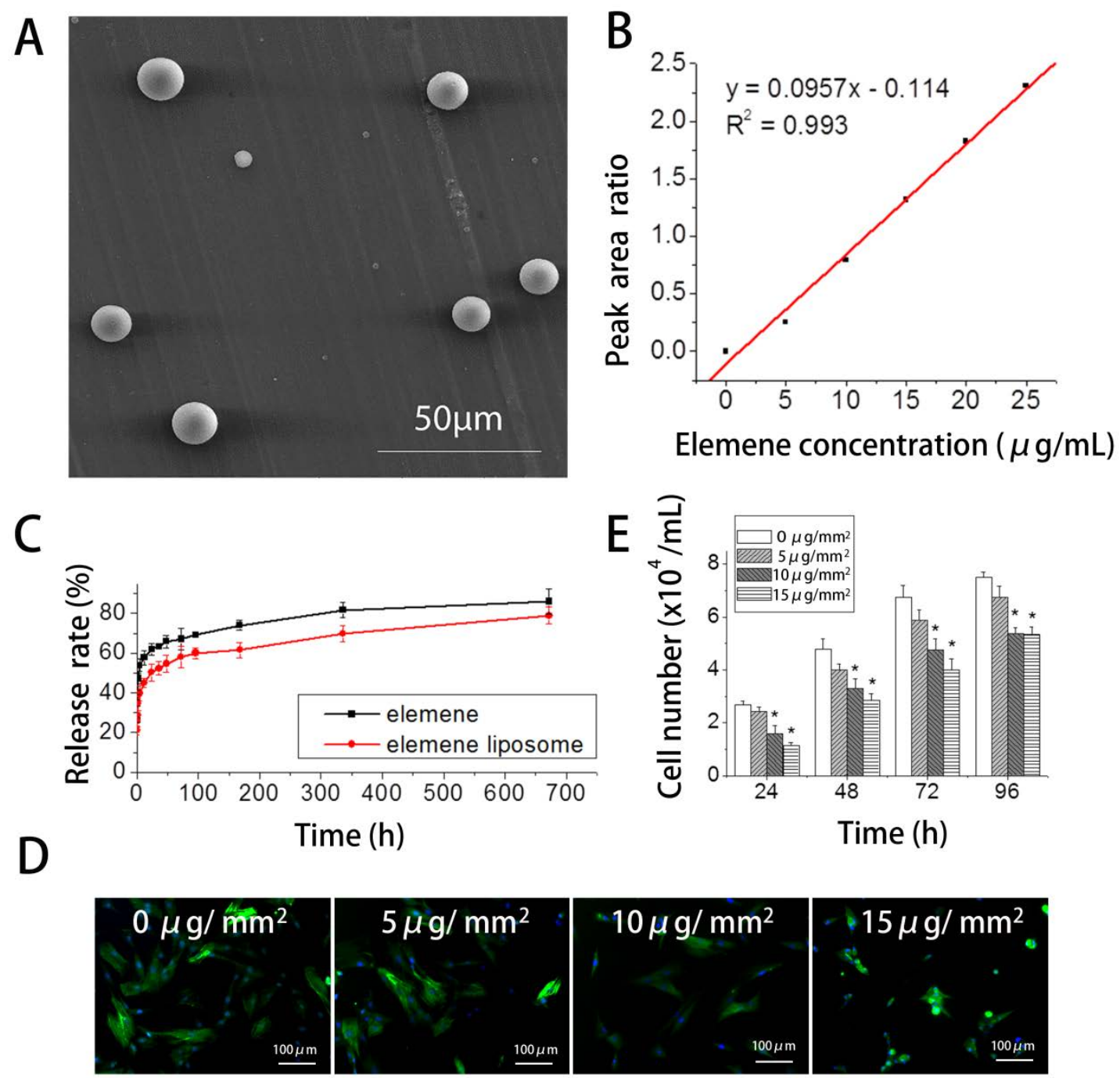

Figure 4. Characteristic of elemene liposome and the effect of elemene liposome membranes on VSMCs proliferation.

(A) Optical image of spherical element particle. (B) The standard curve of elemene liposome. A linear equation is fitted to the curve. (C) Elemene has been released $40 \%$ of elemene injection membranes within $1 \mathrm{~h}$ and another $46 \%$ released in the followed 28 days. While; $28 \%$ released from the elemene liposome membrane at the first $1 \mathrm{~h}$ and more than 20\% remained on it after 28 days. (D) The fluorescence images of cells after co-cultured for 24h. (E) This effect of elemene liposome membranes on VSMCs proliferation is also dose dependent. ( ${ }^{*} \mathrm{P}<0.05$ vs. no elemene treated).

The liposome membrane inhibits VSMCs 
To verify the elemene released from this liposome membranes, we have prepared three types elemene liposome membranes with different concentration of elemene (Figure 4D) by electrostatic spray. After co-cultured with VSMCs for 24h, with the increased content of elemene the cell number and cell spreading area on the membranes decreased and cell edge became much rougher (Figure $4 \mathrm{E})$.

\section{Elemene-coated stents promote endothelialization}

Elemene-coated stents was prepared by electrostatic spraying onto 316L stainless steel vascular stents. The coating surface was uniform as observed by scanning electron microscope and stereomicroscope (Figure 5A, B, C, D).

There was no vessel perforation, laceration, aneurysm or acute thrombosis observed after implantation in the iliac arteries. One week after stent implantation, the surface of elemene-coated and the 316L stainless steel control stents showed no neointima formation. Few platelets and red blood cells were attached on the uncoated steel stent. 4 weeks after implantation, the surface of elemene coated stent has been covered with neointima completely. The cells arranged according to the direction of blood flow, without cell aggregation and cell adhesion. While the surface of 316L stainless steel stents was partially covered with neointima with some parts of the stents were exposed to the blood flow (data not show). 12 weeks later, the surface of elemene-coated stents and uncoated 316L stainless steel stents were covered by a continuous layer of neointima. There was a small amount of platelet and no thrombosis appeared on the neointimal surface in elemene coated stents. In contrast, a large number of platelet aggregation and deformation were observed for the surface of uncoated group (control group) (Figure 5E, F, G, H). 

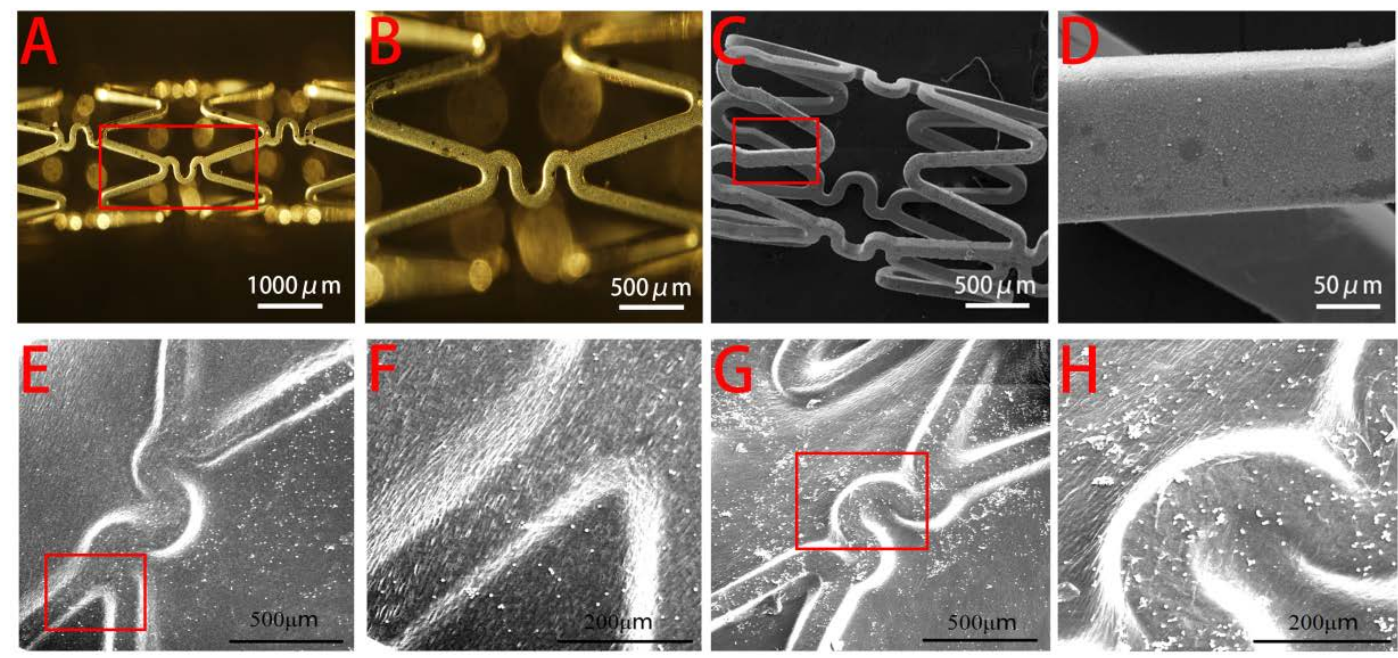

Figure 5. Elemene-coated stents and its animal experiment.

(A, B) Stereo microscope images of elemene-coated stents prepared by electrostatic spray. (C, D) SEM images of elemene-coated stents prepared by electrostatic spray. (E, F) After stent implantation for 12 weeks, the elemene-coated stents surface was covered a layer of complete neointima and there are small amount of platelet adhesion and no thrombosis appears. (G, $\mathbf{H})$ In the control group, a number of platelet adhesion and obvious aggregation and deformation were found on the 316L steel stents surface.

\section{Discussion}

A key cause of ISR is due to VSMCs excessive proliferation, migration to the intima and secretion of large amounts of extracellular matrix protein due to intimal injury. The factors that cause abnormal VSMCs response are multifaceted, including multiple cytokines, growth factors and mechanical factors caused by the environmental changes. The drugs currently used to inhibit ISR also suppress proliferation and migration of VSMCs ${ }^{20}$. The most common DES that is coated with rapamycin and paclitaxel can effectively inhibit VSMCs proliferation and migration ${ }^{21}$. However, stent thrombosis, restenosis and other side effects do occur at a later stage and have raised considerable concerns ${ }^{22,23}$. 
A significant amount of basic research results and clinical applications have demonstrated that elemene is a broad-spectrum and highly effective anti-tumor drug ${ }^{24,25}$. Its anti-tumor mechanisms, such as its ability to induce apoptosis, suspend cell cycle, inhibit proliferation of endothelial cell and expression of vascular endothelial growth factor and inhibit tumor angiogenesis, have been elucidated.

Researchers have also shown that $\beta$-elemene can inhibit neointimal hyperplasia and thrombosis, improving blood rheology function ${ }^{12}$. It may also have anti-oxidative and anti-inflammatory properties. Wu et al have studied the effect of elemene on rat carotid artery balloon injury restenosis and found that it reduced neointimal area and effectively reduced ISR with no thrombosis ${ }^{16}$. These research have suggested that elemene can be potentially applied to inhibit atherosclerosis and restenosis after PTCA.

The experimental results of these studies suggest that inhibition of VSMCs proliferation by elemene is dose and time-dependent. PCNA is known to be an important factor in regulating cell cycle. Almost all the cells in $G_{0} \sim G_{1}$ phase have no obvious expression of PCNA, while the expressions increase significantly in $G_{1}$ and reach the peak in $S$ phase, then decrease in $G_{2} \sim M$ phase 26. Zhao et al have shown that inhibiting the expression of PCNA in VSMCs is an ideal way to inhibit the proliferation of VSMCs and intimal hyperplasia ${ }^{27}$.

Proto-oncogenes, including c-myc, c-fos, are the initiating factors of SMC proliferation. In this study, it is found that c-myc has made VSMCs to get into the stage of the cell cycle and cell proliferation earlier. When VSMCs proliferate, c-myb overexpresses and $\mathrm{Ca}^{2+}$ increase significantly. It has demonstrated that the expression of PCNA and the level of intracellular $\mathrm{Ca}^{2+26}$ was correlated. The CLSM measurements have shown that elemene could increase intracellular $\mathrm{Ca}^{2+}$ firstly, and 
then decrease back to normal level. $\mathrm{Ca}^{2+}$, an important second messenger, involved in signaling pathways that is closely related to cell migration ${ }^{28}$. A variety of active peptide molecules promotes proliferation in a common pathway. Elemene changes free calcium in VSMCs and triggers signal transduction. After VSMCs are stimulated by elemene, calcium is released and the $\mathrm{Ca}^{2}+$ channels open, leading to the massive influx and reducing the discharge of $\mathrm{Ca}^{2+}$. All these factors cause the increased amount of the free $\mathrm{Ca}^{2+}$ in cells, which then lead to early apoptosis of the cells. Biological features of the plasma membrane changed. The $\mathrm{Ca}^{2+}$ within cells flew out quickly, leading to decrease in the $\left[\mathrm{Ca}^{2+}\right]$ level. $\mathrm{Ca}^{2+}$ bound calmodulin to form a complex and active calmodulin kinase II. This triggers series of intracellular signaling chain reaction and leads to a series of cells pathophysiological changes such as cell migration, adhesion, and proliferation ${ }^{29}$.

It is speculated that inhibiting cell proliferation is related to controlling cell cycle and inducing apoptosis. Numerous studies ${ }^{12}$ have found that elemene could interfere cell metabolic pathways. The proportion of cells increased for $\mathrm{G}_{0} / \mathrm{G}_{1}$ phase but decreased for $S$ phase. Through inhibiting cell proliferation, elemene leads to rapid apoptosis. The study by Lu and Xiang has found that elemene can inhibit the activity of telomerase to cause cell apoptosis. By detecting the expression of apoptotic genes (caspase3, caspase7, caspase9), Chen et al have demonstrated that mRNA expression levels of these pro-apoptotic molecules increased significantly ${ }^{30}$. Elemene can also increase the expression of P53 and such effect is dose-dependent. How elemene induces apoptosis and inhibits proliferation is related to P53 anomalous expression. This study shows that elemene change the number and morphology of VSMCs. Cells are disordered and sparse, and the spreading area is significantly reduced. Elemene has a dose-dependent effect on interrupting the connection between cells. Connexin 43 (Cx43) ${ }^{31}$, a cardiovascular tissue connexin, participates in a variety of 
biological activities ${ }^{32,33}$, such as smooth muscle cell contraction, cell growth regulation, tumor growth inhibition, and nerve conduction. Elemene reduces the expression of Cx43 in a dosedependent way.

Other studies found that the development of ISR is clearly related to the mechanical environment of vessel segments after stent implantation ${ }^{34,35}$. With the combined effect of stent expansion and blood flow, vessel wall experiences pressure, tension and shear flow ${ }^{36}$. VSMCs sensed the change of mechanical environment, which will then regulate the intracellular responses. Shi and Tarbell ${ }^{5}$ found that mechanical load could induce the change of VSMCs phenotype. Cell length increased significantly and the proliferation and migration are enhanced. Vascular matrix is degraded and VSMCs proliferation and migration caused vascular lesions ${ }^{37}$. In vitro, culturing VSMCS under fluid shear stress and cyclic strain simulates the changes of mechanical environment in the blood vessels after stent implantation. In the selection of $4 \times 44 \mathrm{k}$ gene expression profiles of IncRNA chip, 1417 gene expressions have differences (over twice), where 699 gene expression levels went up, and 718 went down. About 34 gene expressions are involved the signaling pathways, including PPAR, MAPK, AKT and ERK1/2. MAPK is an intersection signal transmission in cells to stimulate VSMCs proliferation and differentiation. MAPK is mainly composed of three members: ERK, SAPK (also called JNK) and protein kinase P38 MARK. ERK kinase composed a number of chains are the most important MAPK system that can be integrated with RTK and GPCR to transfer and mediate multiple intracellular signaling pathways. RTK activated membrane-associated protein complex and catalyzed GTP to active Ras. Ras after activation enabled serine-threonine protein kinases prime Raf 1 and MAPK kinase (MAPKK) phosphorylation activated and MAPK to be further activated. MAPK activated after the cytoplasm and nucleus reactions can cause primary, 
secondary gene responses, the regulation of cell growth, proliferation, differentiation, and other biological processes. Redondo reported that VSMCs proliferation requires P38 MAPK. PDGF-BB was adopted to activate P38 MAPK and thus stimulate cell proliferation of in vitro Wistar rat aorta VSMCs ${ }^{38}$. A series of abnormal behavior of VSMCs is a result of many factors, such as abnormal expression of a variety of related proteins and multiple signaling pathways.

Previous studies have demonstrated that the anti-cancer activity of elemene is mainly owing to its inhibition of tumor cell growth and induction of tumor cell death in vitro and in vivo. This study has demonstrated that the elemene has significant influence to VSMCs.

However, despite its beneficial pharmacological effects, elemene suffers from poor water solubility and limited bioavailability ${ }^{11}$. In addition, the elemene injection can cause serious venous irritation and phlebitis in clinical practice. Taken together, these factors limit the clinical application of $\beta$-elemene, therefore, a suitable formulation of the drug is required to overcome these drawbacks. The liposome, as a novel drug delivery system, shows significant advantages. For example, it can enhance drug stability, reduce toxicity, achieve target direction action, and long-term sustained release. Zeng et al's study showed that the elemene O/W microemulsion with good clarity, excellent stability, high entrapment efficiency ${ }^{39}$, and improved bioavailability can be prepared successfully using elemene as the oil phase and drug. Shi et al have synthesized $\beta$-E-NLCs by hot melting highpressure homogenization method ${ }^{40}$. The results of TEM imaging of the $\beta$-E-NLCs have revealed that the $\beta$-E-NLCs are spherical and the average diameter of the freshly prepared liposome is 138.9 $\pm 4.7 \mathrm{~nm}$. The elemene liposome in our experiment is spherical with average particle size of 115.6 $\pm 2.1 \mathrm{~nm}$.

Electrostatic spraying is an important technology for preparing the drug-eluting stent. Different 
elemene liposome membranes are prepared by adjusting the electrostatic spray parameters, such as voltage, current velocity, spray distance, and spray time. In our study, smooth and uniform coating to the stent surface was achieved. Besides TEM and dynamic laser light scattering, the amount of loading drug in the liposome and the entrapment efficiency of the liposome can be evaluated by high-performance liquid chromatography and gas chromatography.

The angiography results suggest that the procedures used for stent implantation were successful. Although rapamycin and paclitaxel-eluting stents have an obvious effect on inhibiting restenosis, the inhibition of cell proliferation often delay endothelialization, which will affect endothelial function and cause thrombosis ${ }^{41-43}$. Huo et al have detected the effects of elemene emulsion ( $\beta$-EE) on rat platelet aggregation and the levels of 6-keto-prostaglandin F1 alpha (keto-PGFl $\alpha$ ) and thromboxane B2 (TXB2) in plasma ${ }^{44}$. They speculated that the inhibition of platelet aggregation by $\beta$-EE can result from the increased ratio of PGI2/TXA2. Our study has shown that 3 months after stent implantation, a layer of complete neointima formed on the elemene coated stent surface together with a few platelets attachment and no thrombosis was observed. However, for 316L stainless steel stent, a number of platelets were attached on the stent and cell aggregation were observed. It has been previously demonstrated that elemene-coated stents can significantly promote the reendothelialization of the stent implantation site. And our previous results indicate that elemene is effective in protecting the endothelial cells from injury induced by hydrogen peroxide in vitro ${ }^{16}$. In addition, compared to the control group, elemene-coated stents has also demonstrated some degree of anti-thrombotic effects.

\section{Conclusions}


In summary, this study has investigated the pharmacological characteristics of elemene on proliferation and apoptosis of VSMCS. In vitro results have shown that elemene has the capability to inhibit VSMCS proliferation in a dose-dependent and time-dependent manner, arrest cell cycle, interrupt cell connections, as well as induce cell differentiation and apoptosis. Although the exact mechanism remains to be elucidated, the findings of this study has laid solid foundation for further evaluation of elemene's potential clinical application to prevent neointimal hyperplasia and restenosis, which are associated with oxidative stress, expansion of VSMCS and injury of surface endothelial coverage in vascular blood vessels.

\section{Acknowledgements}

This study is supported by grants from the National Natural Science Foundation of China (31370949, 11332003, 81400329), the National Key Technology R\&D Program of China (2016YFC1102305), the Fundamental Research Funds for the Central Universities (106112016CDJXZ238802, 106112015CDJZR235514), and the Visiting Scholar Foundation of Key Laboratory of Biorheological Science and Technology (Chongqing University), Ministry of Education (CQKLBST-2016-003) as well as Science and Technology Commission of Yuzhong District in Chongqing (20150135). We also thank the support from the China Scholarship Council (academic visitor fellowships to Dr. Tieying Yin and Dr. Yazhou Wang), the Chongqing Engineering Laboratory in Vascular Implants and the Public Experiment Center of State Bioindustrial Base (Chongqing). Dr Jinju Chen like to acknowledge the UK Engineering and Physical Sciences Research Council (EPSRC) for funding (EP/K039083/1). 
References 
[1] G. D. Dangas, B. E. Claessen, A. Caixeta, E. A. Sanidas, G. S. Mintz and R. Mehran, J. Am. Coll. Cardiol., 2010, 56, 1897-1907.

[2] W. Mamuti, A. Ablimit, W. Kelimu, F. Rao, A. Jiamali, W. Zhang, X. Pei and F. Zhang, Int. J. Cardiol., 2015, 179, 424-429.

[3] S. O. Marx, H. Totary-Jain and A. R. Marks, Circ. Cardiovasc. Interv., 2011, 4, 104-111.

[4] C. Chaabane, F. Otsuka, R. Virmani and M. L. Bochaton-Piallat, Cardiovasc. Res., 2013, 99, 353-363.

[5] Z. D. Shi and J. M. Tarbell, Ann. Biomed. Eng., 2011, 39, 1608-1619.

[6] J. J. Chiu and S. Chien, Physiol. Rev., 2011, 91, 327-387.

[7] J, Qiu, Y. Zheng, J. Hu, D. Liao, H. Gregersen, X. Deng, Y. Fan and G. Wang, J. R. Soc. Interface., 2013, 11, 20130852

[8] A. Curcio, D. Torella and C. Indolfi, Circ. J., 2011, 75, 1287-1296.

[9] F. Otsuka, M. Vorpahl, M. Nakano, J. Foerst, J. B. Newell, K. Sakakura, R. Kutys, E. Ladich, A. V. Finn, F. D. Kolodgie and R. Virmani, Circulation, 2014, 129, 211-223.

[10] A. A. Leung, D. A. Southern, P. D. Galbraith, M. L. Knudtson, A. C. Philpott, W. A. Ghali and APPROACH Investigators, Can. J. Cardiol., 2013, 29, 1616-1622.

[11] Q. Q. Li, G. Wang, F. Huang, J. M. Li, C. F. Cuff and E, Reed. Med. Oncol., 2013, 30, 488.

[12] L. Wu, G. Wang, S. Tang, G. Long and T. Yin, Cardiovasc. Drugs. Ther., 2011, 25, 233-242.

[13] Q. Dong, T. Yin and G. Wang, Sheng Wu Yi Xue Gong Cheng Xue Za Zhi, 2013, 30, 656-660.

[14] Q. Y. Li, F. Han, T. Chen, C. Chen, P. H. Yin, Y. F. Chen and D. X. Feng, Cancer Research on Prevention and Treatment, 2010, 37, 287-290. 
[15] L. Y. Wu, G. X. Wang, S. T. Tang, G. Long and T. Y. Yin, Cardiovasc. Drugs. Ther., 2011, 25, 233-242.

[16] R. Zhang, A. Tian, X. Shi, H. Yu and L. Chen, Int. Immunopharmacology., 2010, 10, 738743.

[17] H. F. Ding, S. C. Huang, J. W. Li, X. D. Chen, B. Y. Chen and P. Wu, J. Med. Res., 2011, 40, 71-73.

[18] M. Wang, K. Ihida-Stansbury, D. Kothapalli, M. C. Tamby, Z. Yu, L. Chen, G. Grant, Y. Cheng, J. A. Lawson, R. K. Assoian, P. L. Jones and G. A. Fitzgerald, Circulation, 2011, 123, 631639.

[19] J. Liu, Y. Ren, L. Kang and L. Zhang, Int. J. Mol. Med., 2014, 33, 1341-1347.

[20] Y. Cho, H. M. Yang, K. W. Park, W. Y. Chung, D. J. Choi, W. W. Seo, K. T. Jeong, S. C. Chae, M. Y. Lee, S. H. Hur, J. K. Chae, I. W. Seong, J. H. Yoon, S. K. Oh, D. I. Kim, K. S. Park, S. W. Rha, Y. S. Jang, J. H. Bae, T. J. Hong, M. C. Cho, Y. J. Kim, M. H. Jeong, M. J. Kim, S. K. Park, I. H. Chae, H. S. Kim and KAMIR Investigators, J. Am. Coll. Cardiol. Intv., 2010, 3, 498-506.

[21] J. R. Hasenstein, H. C. Shin, K. Kasmerchak, D. Buehler, G. S. Kwon and K. R. Kozak, Mol. Cancer. Ther., 2012, 11, 2233-2242.

[22] M. Bikkina and J. Koneru, Med. Devices., 2011, 4, 117-124.

[23] G. P. Mishra, D. Nguyen and A. W. Alani, Mol. Pharm., 2013, 10, 2071-2078.

[24] S. Zhao, J. Wu, F. Zheng, Q. Tang, L. Yang, L. Li, W. Wu and S. S. Hann, J. Cell. Mol. Med., 2015, 19, 630-641. 
[25] J. S. Liu, X. M. Che, S. Chang, G. L. Qiu, S. C. He, L. Fan, W. Zhao, Z. L. Zhang and S. F. Wang, World. J. Gastroenterol., 2015, 21, 9945-9956.

[26] W. Strzalka and A. Ziemienowicz, Ann. Bot., 2011, 107, 1127-40.

[27] Y. Zhao, M. Lv, H. Lin, Y. Cui, X. Wei, Y. Qin, K. Kohama and Y. Gao, Res. Commun., 2013, 432, 488-493.

[28] T. D. Craggs, R. D. Hutton, A. Brenlla, M. F. White and J. C. Penedo, Nucleic. Acids. Res., 2014, 42, 1857-1872.

[29] X. Guo, C. Zhou and N. Sun, Biochem. Biophys. Res. Commun., 2011, 407, 807-812.

[30] H. Chen, L. Shi, Z. Y. Cheng, L. Yao, Y. Y. Yang and L. Pan, Zhongguo Shi Yan Xue Ye Xue Za Zhi, 2010, 39, 1048-1050.

[31] C. N. Joshi, D. N. Martin, P. Shaver, C. Madamanchi, B. J. Muller-Borer and D. A. Tulis. Front. Physiol., 2012, 3, 220.

[32] S. R. Johnstone, B. M. Kroncke, A. C. Straub, A. K. Best, C. A. Dunn, L. A. Mitchell, Y. Peskova, R. K. Nakamoto, M. Koval, C. W. Lo, P. D. Lampe, L. Columbus and B. E. Isakson, Circ. Res., 2012, 111, 201-211.

[33] Y. Shi, X. Hou, X. Zhang, Y. Wang, Y. Chen and J. Zou, J. Agric. Food. Chem., 2013, 61, 10534-41

[34] J. Charonko, S. Karri, J. Schmieg, S. Prabhu and P. Vlachos, Ann. Biomed. Eng., 2010, 38, 889-902.

[35] C. Z. Chiu, B. W. Wang and K. G. Shyu, J. Biomed. Sci., 2013, 20, 50.

[36] X. Mao, R. Said, H. Louis, J. P. Max, M. Bourhim, P. Challande, D. Wahl, Z. Li, V. Regnault and P. Lacolley, Cardiovasc. Res., 2012, 96, 513-23. 
[37] J. Qiu, Y. Zheng, J. Hu, D. Liao, H. Gregersen, X. Deng, Y. Fan and G. Wang, J. R. Soc. Interface., 2013, 11, 20130852.

[38] S. Redondo, E. Ruiz, A. Gordillo-Moscoso, J. Navarro-Dorado, M. Ramajo, M. Carnero, F. Reguillo, E. Rodriguez and T. Tejerina, PLoS One, 2010, 5, e9800.

[39] Z. Zeng, G. Zhou, X. Wang, E. Z. Huang, X. Zhan, J. Liu, S. Wang, A. Wang, H. Li, X. Pei and T. Xie, Int. J. Nanomedicine., 2010, 5, 567-572.

[40] F. Shi, G. Yang, J. Ren, T. Guo, Y. Du and N. P. Feng, Int. J. Nanomedicine., 2013, 8, 25332541.

[41] F. Bozsak, D. Gonzalez-Rodriguez, Z. Sternberger, P. Belitz, T. Bewley, J. M. Chomaz and A. I. Barakat, PLoS One, 2015, 10, e0130182.

[42] H. Li, L. J. Zhang, B. H. Chen, X. Zhou, K. Su, W. T. Shi, J. Z. Wu, H. Yu and L. Wei, Pharmacology, 2010, 85, 136-145.

[43] M. Hamilos, F. Ribichini, M. C. Ostojic, V. Ferrero, D. Orlic, C. Vassanelli, N. Karanovic, G. Sarno, T. Cuisset, P. E. Vardas and W. Wijns, J. Cardiovasc. Transl. Res., 2014, 7, 406-12.

[44] W. M. Huo, W. L. Duan, J. Liu and J. Shang, Asia-Pacific Traditional Medicine, 2013, 9, 3033 


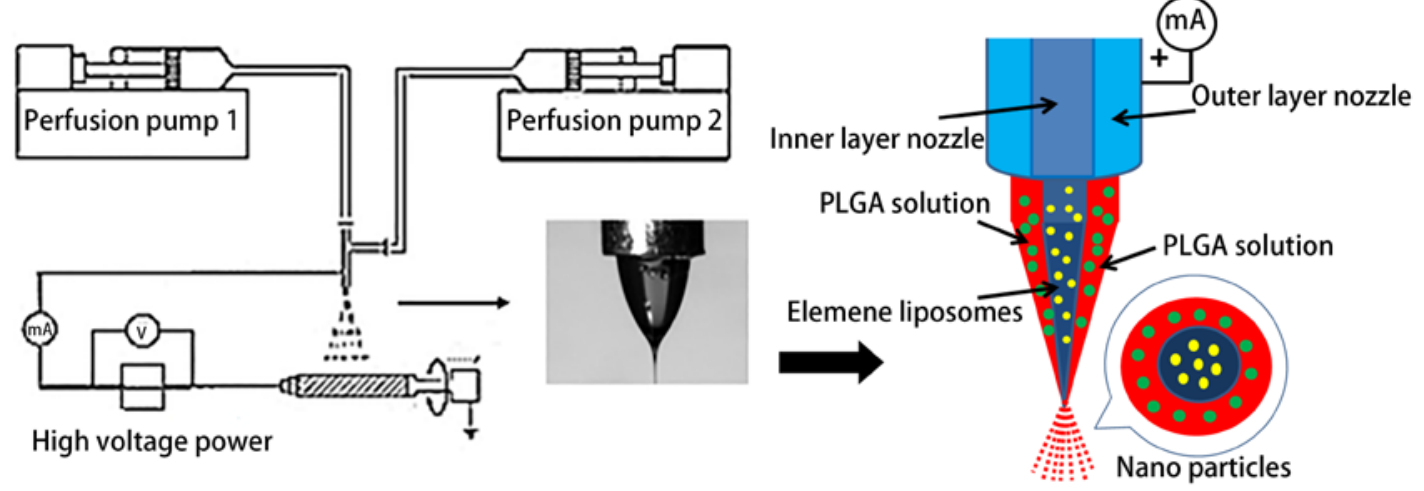

Supplementary Figure S1. The diagrammatic sketch of electrostatic spray elemene lipidosome membranes and elemene-coated stents. 